\title{
EVALUATION OF TOURIST MOTIVES/ ATTRACTIONS IN SARAJEVO TOURISM DESTINATION
}

\author{
Lejla Žunić ${ }^{1}$
}

\begin{abstract}
Sarajevo is the most important cultural and tourism center of Bosnia and Herzegovina ( $1 / 3$ of the total national tourism). It hasvery valuable tourism motives (natural and anthropogenic). Statistical indicatorsshows a positive trend of tourism development during the last decade. It is therefore very important to analyze tourist motives and their importance for the development of tourism. Tourist motives are the main supply holders. The significance of a motive is determined by various criteria which in most cases involve the assessment of several elements: attractiveness, rarity, usefulness and accessibility. However, the tourism value of motives is largely reflected through impressions of tourists. Travel experience is especially important element of tourism which affects the affirmation of destinations in the world and encourages tourism trends. The research problem is the identification and evaluation (valorisation) models of motives in Sarajevo determining their significance.The research is quantitative and qualitative. Research methods are: general-theoretical (analysis and synthesis,comparing, classification);empiric (field work and observation, survey, measuring);identification, evaluation, Likert method. The aim of the paper is to determine the actual tourism value of the motives for better planning of tourism supply. Of particular importance are the results of tourist assessments of the motives because the ultimate goal is to achieve the satisfaction of tourists and positive echo of the destination in the world. Therefore motives such as Bascarsija, Tunnel of Hope, Springs of river Bosnia and Bijambare should take leadership role in Sarajevo tourism planning and development of tourism destination.
\end{abstract}

Key words: Sarajevo tourism destination, motives/ attractions, tourism supply, importance of tourism, tourist impression, evaluation, tourism planning, development of tourism.

\section{INTRODUCTION}

Sarajevo tourism destination is located in the Sarajevo valley which covers SE sector of the Sarajevo-Zenica basin within the Dinaric mountain-valley system of Bosnia and Herzegovina (Bušatlija, 1974). The morphology of the terrain is divided into two visible natural units: inner flattened area with the Sarajevo field and highlands circumference (Đug, Drešković, Hamzić, 2008), which is called the "green ring" of Sarajevo due to recognizable biodiversity (Spatial Plan of the Canton of Sarajevo 20032023, 2006). The lower area is under moderate climate while the highlands above 1000 $\mathrm{m}$ is mountain climate (Köppen climate types: Cf, Df) which has recognized tourism value. The historical and geographical development of the destination is complex (the Illyrians and Romans, Medieval Bosnia "Vrhbosna", the Ottomans, the AustroHungarian Empire, the Kingdom of Serbs, Croats and Slovenes, Yugoslavia,

\footnotetext{
${ }^{1}$ Doctor of Geographical Sciences, Department of Geography, Faculty of Science, University of Sarajevo, Zmaja od Bosne 33 -35, 71000 Sarajevo; pmflejlazunic@yahoo.com.
} 
independent $\mathrm{BiH}$ since 1992, the war and aggression against Bosnia and Herzegovina, post-war phase of restoration), which has resulted in a rich cultural and historical legacy, and the motives of the Ottoman and Austro-Hungarian period have the highest value (Spatial plan of Bosnia and Herzegovina, 1980; Spatial plan of Canton Sarajevo, 2006; Commission to Preserve National Monuments). Sarajevo has a favorable geostrategic and geotraffic position because it is the natural crossroad of communications that connect geographically distant and different places (Bakaršić, 1966). Sarajevo has a favorable tourism-geographical position (Fig.1.) because it is located in one of the most important European tourism corridors which is used by Central European tourists to circulate towards the south, that is the Adriatic Sea and Mediterranean (Nurković, 2006, pg 31). The destination is developing, the tertiary sector in the overall GDP structure and employment accounts for about $78 \%$ (Federal Bureau for Statistics, 2009) and tourism is increasingly gaining in importance. Tourismflow has a positive upward trend (the overall average growth rate of tourism $10.7 \%$ in 1999-2009). The largest share in the total structure of tourists in 2013 year have Turks, tourists from the region and tourists from the Arab countries(Kuwait, etc.); Arabs create the longest stay (TourismAssociation of Sarajevo Canton). Tourism is based on cultural, religious and historical aspects; promotion and presentation of the motives makes $50 \%$ of the total tourism supply of Sarajevo (Mehičić, 2007).

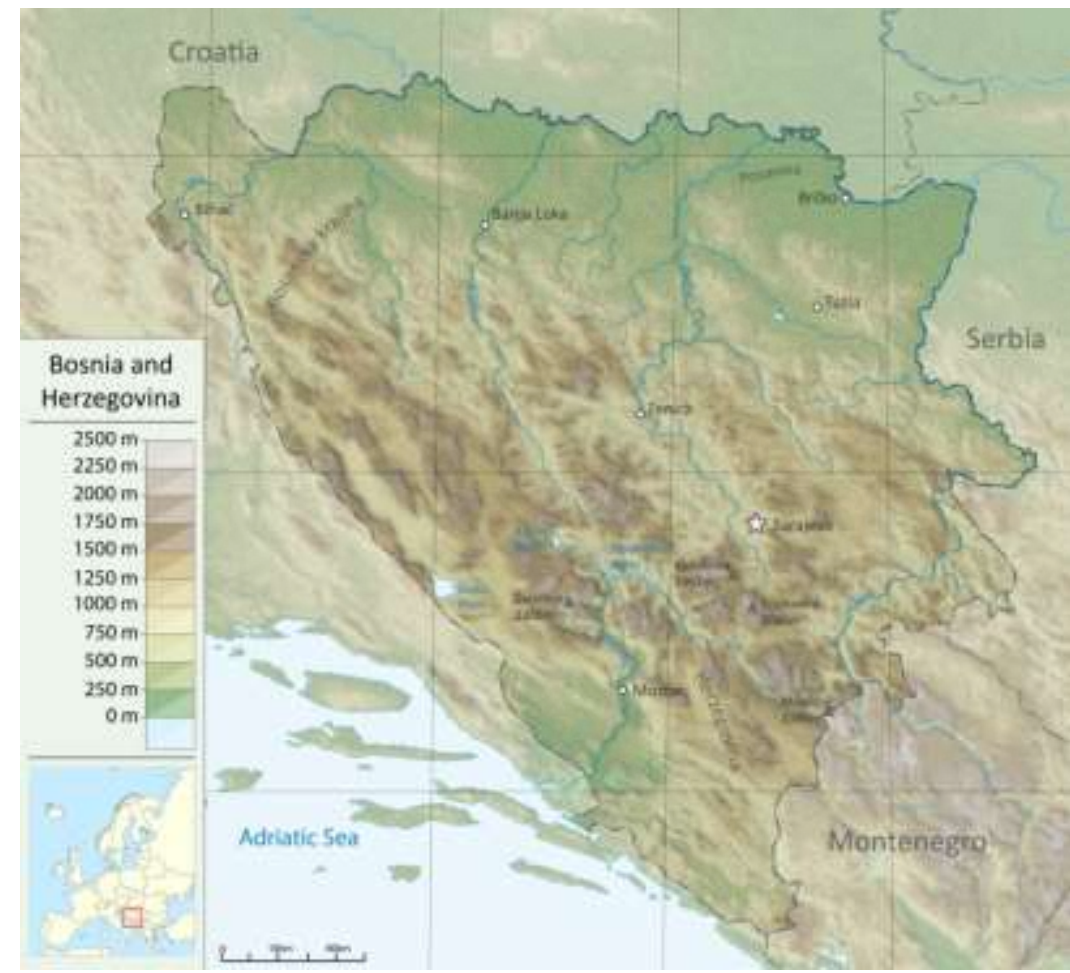

Fig. 1. Geographical position/ location of Sarajevo in the Bosnia and Herzegovina (Wikimedia Commons, Wikimedia Foundation, USA) 


\section{METHODOLOGY}

The research goalis identification and tourism valorisation of the most important motives in Sarajevo tourism destination. The aim of the paper is to carry out identification and evaluation of the motives, and based on the determined value (ranking) to determine their tourism quality. Tourism-geographical valorisation of the motives is carried out by the WTO valuation model (Stanković, 2000), Hilary du Cross (Jašarević, 2012) and Likert (Žunić, 2016). The identification method has enabled the identification of the motives the biggest tourist value depending on the tourist experience. The survey made it possible to come to important insights because of openended and closed-ended questions and epsecially the rating scales.It took two years (2013-2014) and was conducted in Sarajevo tourist destination in the most important tourist sites and included over 100 participants (tourism/ travel managers, touristsvisitors). The survey of managers (20) was carried out in hotels (Bristol 4*, Europe 5*, Art 3*, Terme 4*, Hercegovina 4*, Crystal 4*, Hollywood 4*) and travel agencies (Relax Tours, Gaudi Lufthansa, Bosnia travel, Reyyan, Akdeniz, Euroservices, ZOI'84, Centrotrans, GRAS), while the survey of tourists (107) was carried out at: a) the tourist sites in the old city (the garden of Morića Han, the harem of the Bey's mosque), b) the accommodation units for tourists: hotels (Europa, Radon Plaza, Bristol, Hollywood, Terme, Dardanija, Imzit, Astra Garni, Michele, Old Town, ETN, Mostardayiz, City Boutique, Emona, Lula), hostels (Vagabond, Franz Ferdinand, Kovači, Max, Guest House, For Me, Doctor's House), private accommodation, Sarajevo apartments. The structure of respondents was $40 \%$ tourists of the Arab origin, domestic tourists, foreign tourists (the USA, Canada, Malaysia, Japan, etc.).

\section{RESULTS AND DISCUSSION}

\section{General explanation of the motives and Sarajevo tourism destination (Literature review)}

Tourism motives are natural and anthropogenic objects which can be attractive for tourists (Jovičić, 1992, pg 121). Natural motives could be climate, geomorphologic objects, hydrography, biogeography and landscape, while social/ antropogenic motives are cultural and historical monuments, ethno-social, artistic, manifestation, ambient (Board "Tourism", 2010). Sarajevo tourism destination is the center of meeting cultures, eastern oriental and western European. A rich cultural and historical and architectural heritage was created on the basis of such a development. "At the crossroads of cultures and civilizations, there was created a unique multinational and multi-confessional environment, architecturally presented as a unique example of always stimulating cooperation between East and West.“ (Kurto, 1997, pg 5) It's called by descriptive name "Jerusalem of Europe" (Sarajevo Navigator, 2017) "The territory of Sarajevo has a great wealth and diversity of tourism potential, the most developed 
tourism infrastructure, propulsive tourism marketing and the most extensive tourismflow in Bosnia and Herzegovina (2004: 1/3 of the total state tourist traffic/ tourism flow) and as such has the most recognizable identity of Bosnian and Herzegovinian tourism and geographic region." (Nurković, 2006, pg 31) City ambient (the city core) of Sarajevo is the most important cultural and historic site and the largest area of architectural heritage. It's composed of three zones: the historic site, the historic center and the old historic center. (Spatial Plan of the Canton of Sarajevo 2003-2023, 2006, pg 42) The Sarajevo urban area has an international character ("zero" categorythe highest rank) because it has a special value in terms of uniqueness and rarity at all levels: national, European and world. (Spatial plan of Bosnia and Herzegovina, phase B valorization: natural, cultural and historical value, 1980, pg 21, 53) The uniqueness is reflected right in the mix of cultural diversity and architectural heritage with a distinctive style of the East (Oriental) and West (European). Within the limits of the ambiance area, the biggest tourist attraction, representativeness and ambience has:

- Crafts and trading zone - Baščaršija, and residential zones - city blocks: Logavina, Kovači, Nadmlini, Alifakovac and Podbistrik. This zone consists of the most representative public, religious and residential buildings of the heritage monuments from the Ottoman period. This area has been defined as "the zone of the largest ambient value of Sarajevo." (Spatial Plan of the Canton of Sarajevo 2003-2023, 2006); Oriental centre of the old town.

- The zone that covers the area stretching from Džidžikovac - Hamdije Kreševljakovića and Franjevačka on the other side of the Miljacka river, and consists of the most representative religious, public, residential and office buildings of the architectural heritage from the Austro-Hungarian period, and religious and public monuments of the architectural heritage from the Ottoman period. (Spatial Plan of the Canton of Sarajevo 2003-2023, 2006); mainly the area of the city center.

The importance of the cultural and historical heritage from the Ottoman period is invaluable. "The preserved monuments of material culture, archival documents and testimonies show that the most important period in the urban development of Sarajevo in the Ottoman period was the sixteenth century, which is rightly called the golden age in the history of this city. At the beginning of the 16th century, there was also built the old Orthodox church, then there was the Catholic church in the neighborhood called Latinluk, and at the end of the same century, there was also built the first synagogue II Kal Grandi. Islamic schools were required to be build together with mosques, the most famous madrassa is Kuršumlija, the endowment of the great benefactor Gazi HusrevBey, the Bosnian governor. Sarajevo is the only city in the European part of the Ottoman Empire, which since its founding has become the political, cultural and economic center of the country and has remained such to this day. This means that the country of Bosnia with its capital city had a special status and that the status was guarded by Sarajevo itself.“ (Museum of Sarajevo, 1963) Since 1997, the old urban center of Sarajevo has been submitted for the UNESCO World Heritage List. "According to the criterion (V), Sarajevo- the open city is a unique example of 
traditional human life and settlements. The beauty of the city is reflected not only in a number of architectural monuments but also in the interpretation of the synthesis of environmental harmony and protection of diversity, so that Sarajevo is such a unique, inimitable and unified open area, cosmopolitan city. It also includes criterion (VI) according to which life tradition makes the city unique and universal. There are not so many places that are so rich in diversity of cultural and phenomenological character in a simple natural environment, geographical landscape and the mighty spirit of illumination. The architectural heritage of the pluralist society and multiculturalism of Sarajevo phenomena symbolizes the special attributes that reflect the culture of Bosnia and Herzegovina. They are the most complex spiritual nuclei and symbolic matrix of "Zlatna dolina" (Golden Valley) of an authentic expression." (UNESCO "Culture", World Heritage Centre, "The List", Global Strategy, Tentative List, 2015) Sarajevo is a candidate for nomination to the UNESCO World Heritage List, it is located on the tentative (provisional) list of goods: "Sarajevo- a unique symbol of universal multiculture - permanently open city(01/09/1997)“. (State Commission of Bosnia and Herzegovina in cooperation with the UNESCO, the United Nations, Educational, Scientific and Cultural Organization, 2012) Identification lists of natural and anthropogenic motives of Sarajevo are very extensive, however, the aim of the paper is to establish a list of the most valuable tourist attractions according to impressions of promoters and consumers of the motives. The survey found 17 motives of special value (Table 1.) for which it is necessary to carry out further evaluation. As the evaluation of the motives was made by various authors and relevant institutions dealing with assessment and conservation of natural and cultural-historical heritage, it is necessary to look at earlier research results. According to Nurković (2006), for the evaluation of tourism potentials there were used the following principles: usefulness, rarity and degree of possibility of their tourism valorisation, and as parameters: spatial, qualitative, type of tourism. (Nurković, 2006, pg 34) According to the earlier documentation, the criteria of valorization of natural, cultural and historical motives are: scientific value, rarity of phenomena, typicality of phenomena, cultural and educational importance, environmental value, landscape-design value, recreational value, vulnerability, preservation, presentation and categorization of the motives according to importance (international, national, regional and local value). (Spatial Plan of Bosnia and Herzegovina- Phase B, the valorization of natural, cultural and historical value, 1980, pg 20-21) According to Jašarević and Popara (2012), the valuation parameters of values of motives are: tourism-geographical position, artistic value, environement, attractiveness, development level, compactness, general tourist value and quality range of motives. According to the recent documents, the evaluation criteria of motives are based on an assessment of several elements: time frame, historical value, artistic and aesthetic value, readability (documentary, scientific and educational), symbolism, ambience, authenticity, uniqueness and rarity, compactness. (The Commission to Preserve National Monuments of Bosnia and Herzegovina, The criteria 
for making the decision to designate the property as a national monument, "Official Gazette BiH", 33/02 and 15/03)

Table 1. Evaluation of the tourist motives in Sarajevo destination by different authors

\begin{tabular}{|l|c|c|c|c|c|}
\hline Motive/ Attraction: & S. Nurković & S. Jašarević & E. Popara & PPBH-B & KONS \\
\hline Baščarsija & international & international & international & international & - \\
\hline Gazi H. Bey's mosque & national & international & international & international & national \\
\hline Alifakovac & regional & national & international & national & \\
\hline Tunnel of hope (D-B) & regional & - & regional & - & - \\
\hline The City Hall & national & national & international & national & national \\
\hline Congregational Church & national & national & national & national & national \\
\hline Cathedral & national & national & national & national & national \\
\hline The Old Temple & national & national & national & national & national \\
\hline The Latin Bridge & regional & national & international & national & national \\
\hline Svrzo house & regional & national & national & national & national \\
\hline Ashkenazy synagoge & national & national & national & national & national \\
\hline The Emperor's Mosque & national & national & international & national & national \\
\hline Springs of Bosnia & national & - & - & national & - \\
\hline The Pioneer's Valley & regional & - & - & regional & - \\
\hline Bijambare & regional & - & - & regional & - \\
\hline Waterfall Skakavac & regional & - & - & local & \\
\hline Olympic mountains & international & - & - & national & - \\
\hline
\end{tabular}

(Sources: Nurković, 2006; Jasarević, 2012; Popara, 2012; PPBH-B: Spatial plan of

Bosnia and Herzegovina- phase B, 1980;KONS: Commission to Preserve National Monuments of $\mathrm{BH}$, Resolution for the national monuments declaration and tentativelist of national monuments of Bosnia and Herzegovina, 2005)

According to the table of the motives' evaluation in Sarajevo tourism destination by different authors, it is evident that there is a largely compliant valuation of the motives. Common (equivalent) rating is recognized at the following motives: Baščaršijainternational significance; the Congregational Church, the Cathedral, the old Jewish synagogue, the Ashkenazi sinagoga- a national character; the Bijambare area, the Tunnel of Hope - a regional character. Pronounced differences were identified when evaluating the following motives: Alifakovac, Latin Bridge, the Olympic Mountains.

\section{FINDINGS AND DISCUSSIONS}

In contrast to earlier results that are based on the above criteria and essentially similar evaluation criteria, the results of the survey made it possible to reach new insights by which the evaluation of motives was made primarily on the basis of a common frequency response (estimate) of tourism managers (Fig.2.) and tourists (Fig.3.) who visited Sarajevo tourism destination. It's important because travel/ tourism managers are promotors and "sellers" of motives/ attractions, while tourists are consumers of motives. Travel experience/ tourist impression is particularly important with affirmations of the destination and incentive tourism trends (Hall and Page, 2014). According to Jovičić (1986), experiencing is the most active relation towards the motives and the most 
important cultural element of tourism trends because it implies a longer stay of tourists and rich content of stay, and requires more functional and versatile promotion of tourism". (Jovičić, 1986, pg 39-40) The key elements that influence the decision of tourists to visit a destination are the perception of environment and the principle of the best benefit. Diversity of environment and natural and anthropogenic features that are quite different from the place of residence of tourists encourage tourism trends. Evaluation of motives based on tourist impressions shows that offer in the market is not enough. (Jianchang and Jigang, 1988) Tourist perception and knowledge of destination surrounding, social psychology of tourism and motivation of tourists are important elements of tourism planning. (Hall, Page, 2014, pg 210-211) According to the survey results, an elevated rating of motives of 4.4 was found (tourists 4.3 , travel managers 4.5). According to the proposed evaluation scale (1-5), this rating means the national and wider significance of motives with the tendency of international recognizability. Individual selection of motives depending on personal experiences, opinions and experiences made it possible to reach results regarding the maximum value of individual motives of Sarajevo.

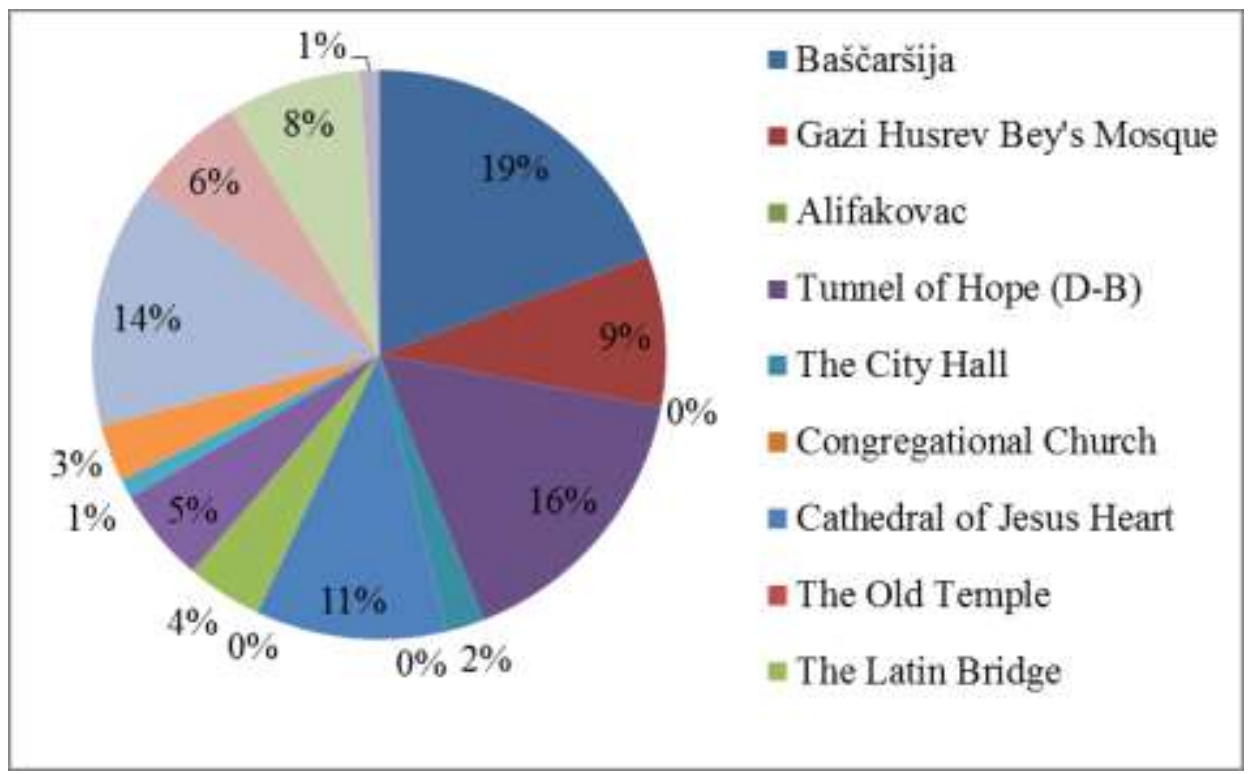

Fig. 2. The most valuable tourist motives/ attractions of Sarajevo according to the evaluation of tourism/ travel managers (Žunić, 2016: Survey for employers in tourism, Sarajevo, 2013) 


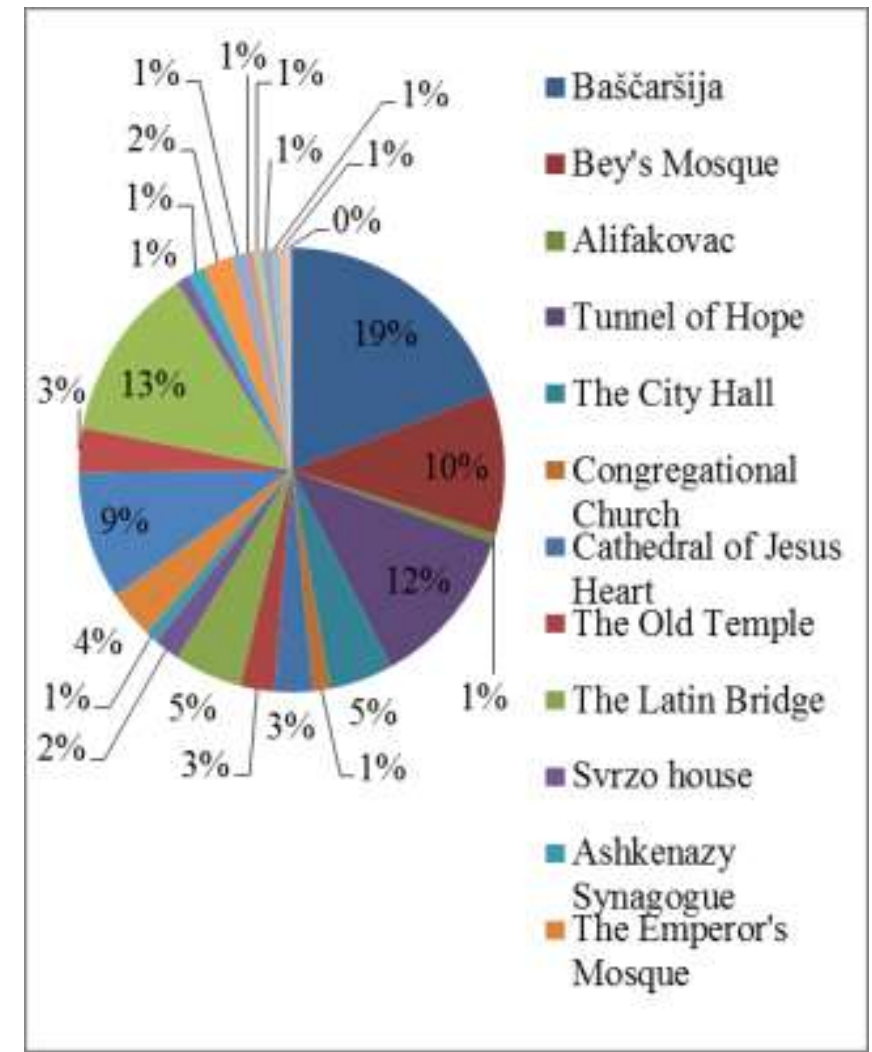

Fig. 3. The most valuable motives/ attractions of Sarajevo according to the evaluation of tourists

(Žunić, 2016: Survey for tourists- visitors, Sarajevo, 2013-2014)

The comparative analysis of the shown diagrams leads to the conclusion that the most valuable attractions in the area are: Baščaršija, the Tunnel of Hope, the spring of the Bosnia river, the Gazi Husrev-Beg Mosque, Bijambare, the Cathedral of the Sacred Heart, etc. (Fig.4.) The ratings of tourism employers mainly match the impressions of tourists noting that, according to the survey results, the emphasized and special value was given to Bijambare and the Gazi Husrev-beg mosque, while less value was given to the Cathedral. A potential reason is the subjectivism affected by a large proportion of respondents of the Arabic and Turkish origin of Muslim religion over 40\%. A high proportion of Arab tourists had a significant impact on favoring Bijambare and the spring of the Bosnia river because they generally prefer natural tourist attractions just because they lack "green landscapes" in their home areas - the arid desert regions of the Arab world create a wish for "green areas" with an abundance of water and biodiversity. Precisely, such tourism potential is offered by Sarajevo tourism destination (the Spring of the Bosnia river, Skakavac, Bijambare Caves with forest and meadow landscape, Olympic mountain). 


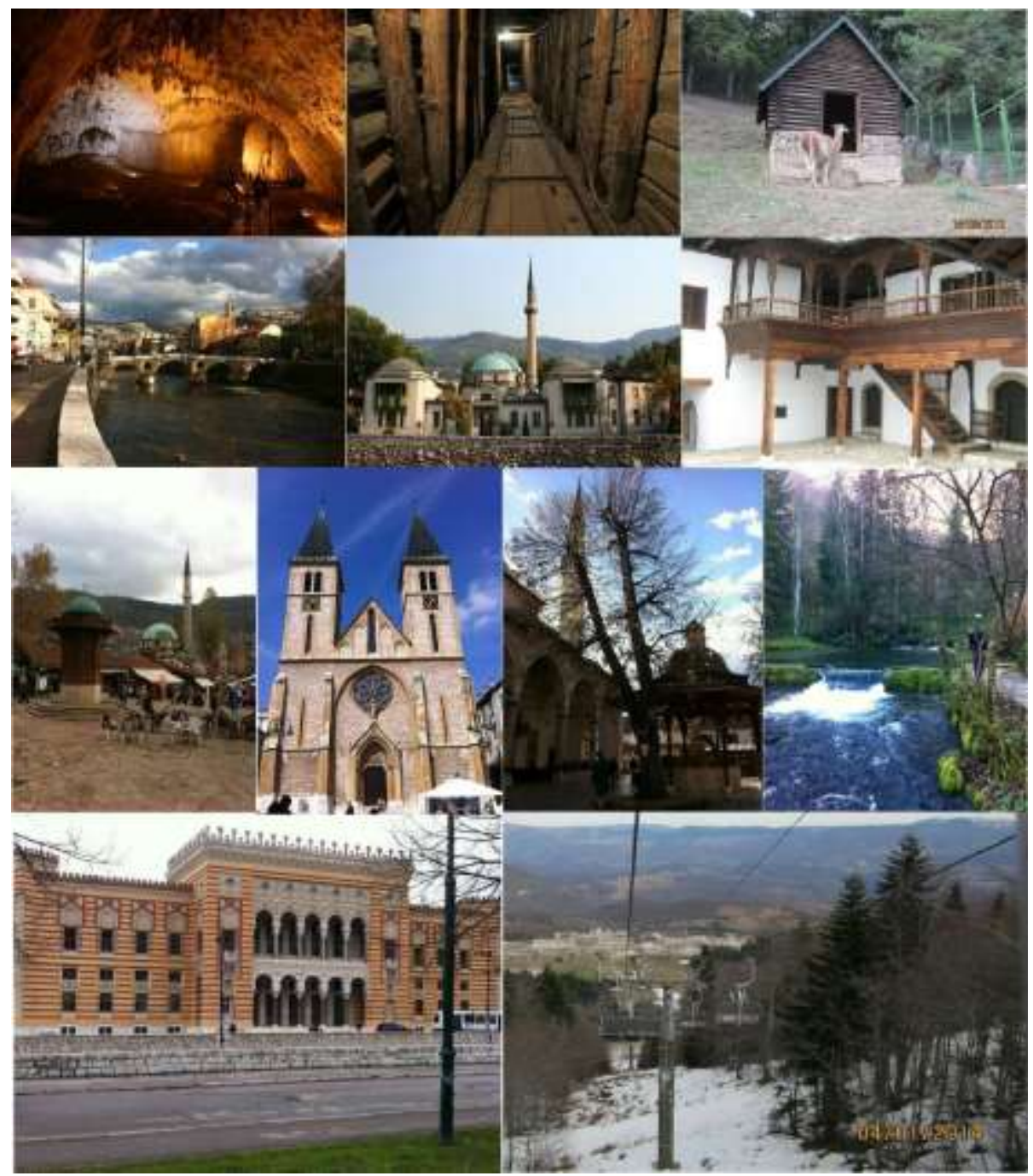

Fig. 4. The most valuable attractions according to touristimpressions (Žunić, 2016)

The importance and value of the motives vary by origin of tourists: Baščaršija is the most valuable motive as seen by domestic tourists but also a large number of foreign tourists (Germany, Kuwait, Turkey), while the Tunnel of Hope has the largest value for foreign tourists from distant parts of the world (the USA, Australia, Malaysia) who feel an emotional connection with the symbolism of the motive.

According to statistical models and scientific criteria in analytical surveys (The Survey Guideline, 2001, pg 23), the majority category and also confirmation of a certain attitude can be considered to be respondence of $60 \%$ and more. (Guideline for surveys, 2001, pg 23) Respondents were asked to complete the selection and favoring of the attractions from the proposed list of tourist motives in the destination according to the value and importance. They were conditioned to opt for three major attractions, which 
was used to establish the criteria for the evaluation of the motives that potentially have the greatest importance:

- $\quad$ Frequency of $60 \%$ or more, corresponding to the highest rate 5 and the international importance of the motive

- $\quad$ Frequency of $60-35 \%$, corresponding to a very good rate 4 , as well as national and wider regional importance

- $\quad$ Frequency of $35-10 \%$, corresponding to a good rate 3 and regional importance of the motive/ tourist attraction

Consequently, on the basis of results ranking by the height of frequencies, for individual motives there was determined the list of the most important motives in Sarajevo tourism destination (Table 2.). Their importance is manifested in the total value and impressions that are reflected in the importance of a greater radius.

Table 2. The final list of the selection of the most important tourist motive/ attraction in Sarajevo tourism destination according to total frequency of evaluation by tourism managers \& tourists (in percentage);

Interval of frequency: $60 \%$ and more - international significance; $60-35 \%$ - the national and wider regional importance; $35-10 \%$ - regional significance/ the importance

\begin{tabular}{|c|c|c|c|c|}
\hline Motive/ Attractions: & $\begin{array}{c}\text { Travel } \\
\text { managers }\end{array}$ & Tourists & Average & $\begin{array}{c}\text { The } \\
\text { importance }\end{array}$ \\
\hline 1. Baščaršija & 90 & 63,2 & 76,6 & International \\
\hline 2. Tunnel of Hope & 75 & 38,9 & 57,0 & National \\
\hline 3. Springs of Bosnia & 65 & 30,5 & 47,8 & National \\
\hline 4. Bijambare & 35 & 42,1 & 38,6 & National \\
\hline 5. Bey's Mosque & 40 & 33,7 & 36,9 & National \\
\hline 6. Cathedral & 50 & 9,5 & 29,8 & Regional \\
\hline 7. Peeonir's Valley & 30 & 10,5 & 20,3 & Regional \\
\hline 8. The Latin Bridge & 20 & 16,8 & 18,4 & Regional \\
\hline 9. Svrzo house & 25 & 6,3 & 15,7 & Regional \\
\hline 10. The City Hall & 10 & 15,8 & 12,9 & Regional \\
\hline 11. The Emperor's Mosque & 15 & 11,6 & 13,3 & Regional \\
\hline
\end{tabular}

(The Survey Guideline, 2001; Žunić, 2016: Survey for employers in tourism, Sarajevo, 2013; Survey for tourists- visitors, Sarajevo, 2013-2014)

Spatial distribution of the most important tourist motives/ attractions in Sarajevo tourism destination is shown at the following map (Fig.5.) 


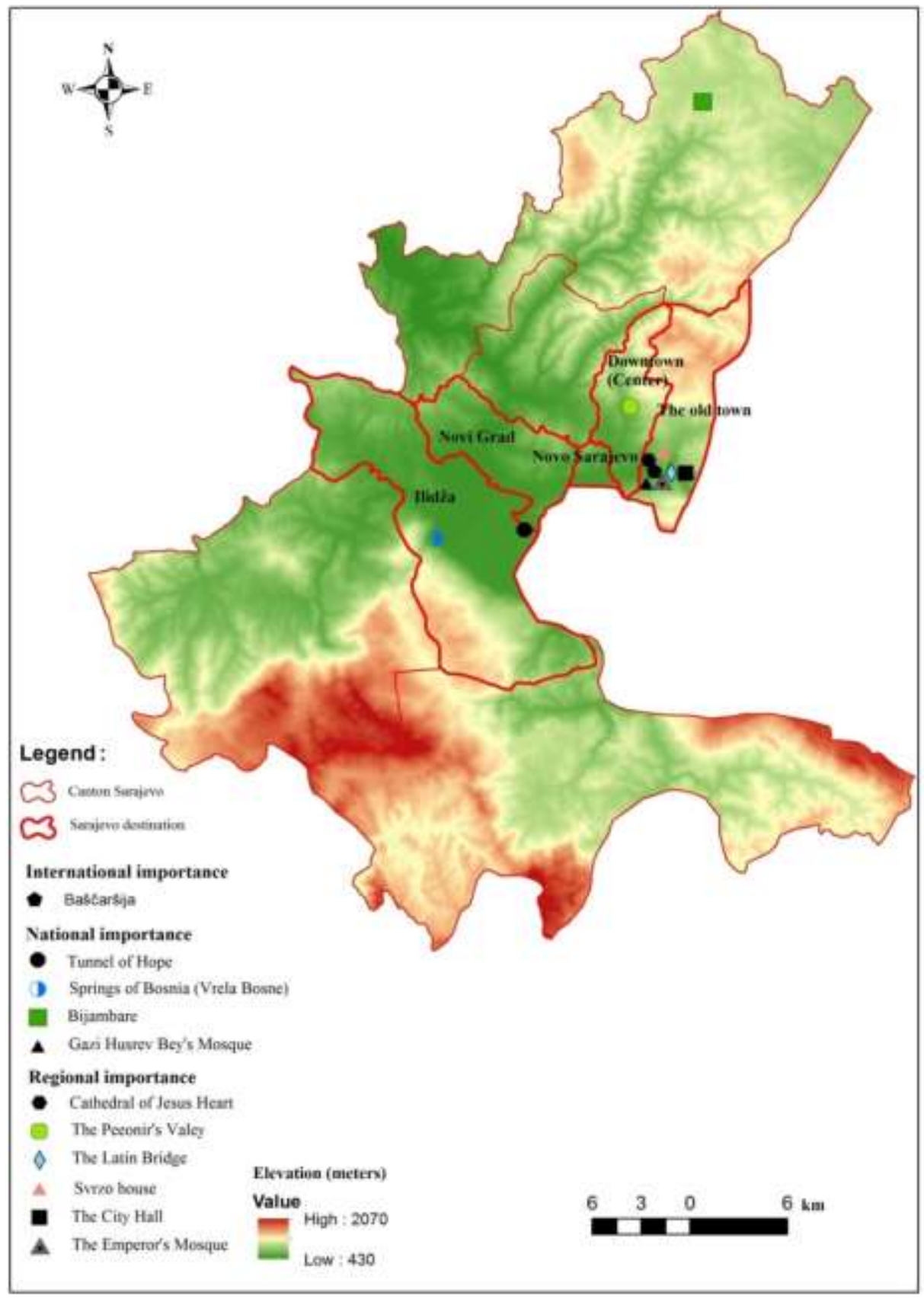

Fig. 5. Spatial distribution of the most valuable tourist motives in Sarajevo tourism destination and their importance according to the frequency of travel managers and tourist impressions

(Žunić, 2016, Sarajevo, 2013-2014)

According to the Map 2 and the table of final selection list of the most important tourist motives in Sarajevo destination (table 2), there were important insights: 
- International importance: Baščaršija.

- National and wider regional importance: the Sarajevo War Tunnel (the Tunnel of Hope), the Springs of the Bosnia River, Bijambare, the Bey's (Gazi Husrev-Bey's) mosque.

- $\quad$ Regional importance: the Cathedral of the Sacred Heart, the Pioneer Valley, the Latin Bridge, Svrzo house, City Hall, the Emperor's mosque.

Environmental complex Baščaršija is the most important tourist site (attrraction) in Sarajevo tourism destination, which represents the oriental cultural and historic center from where mainly started urban and tourism development. Baščaršija (Turkish "baš", main marketplace, Bejtić, 1969, pg 68) was built in the 15th century (1462) when Isa Bey Ishaković founded the city, built the Han (Inn) and many shops on the north bank of the river Miljacka in the old town. The main tourist potential of Baščaršija is the preservation of cultural and historical monuments, shops, old trades. The appearance has remained the same for hundreds of years and preserved itself in this spirit that dates back to the Ottoman period, which contributes to the visit of a large number of guests from all over the world. Baščaršija is the main tourist center and the biggest factor in improving the city tourism supply. The environmental complex of Baščaršija is a candidate for UNESCO's World Heritage List. (Resolution for the national monuments declaration and tentative list of national monuments of Bosnia and Herzegovina, 2003) The same score of the most value and international importance of Baščaršija is established also with other researchers, which confirms its relevance.

Religious buildings, primarily the Ghazi Husrev-Bey's Mosque, is assessed with a high grade and has national and wider regional tourism importance. This mosque is the strongest symbol of the centuries-long Ottoman reign in Sarajevo and Bosnia and Herzegovina, and has a particular cultural and historical value. Earlier assessment of the religious motives mainly determine their national significance. On the other hand, the tendency in recent times is that the Bey's Mosque has been categorized as "zero" category. The Gazi Husrev-Beg Mosque represents the architectural ensemble of international tourist interest, and it consists of: the mosque, the Gazi Husrev-Bey and Murat Bey's tomb, the yard with tombstones, abdesthana (wudhu washing room), Shadirvan (fountain), muvekkithana (room with time measuring instruments) and place of the old mekteb. It is located in the commercial area of the old urban center of Sarajevo, which gives it extremely high environmental value. The famous Gazi HusrevBeg Mosque is in the first row of the most important architectural creations of the Ottoman period in the 16th century and it represents not only the highest achievement in the overall Bosnian-oriental heritage but also the high achievements in the wider relations of Islamic architecture of the time. (The decision to designate properties as national monuments and provisional list of national monuments of Bosnia and Herzegovina, 2003) A characteristic of the interior of the mosque is a beautiful stalactite decoration in the corners under the dome and in the mihrab, and designs and calligraphy on all the walls. (Mehmedović, 2005, pg 67) However, the specificity of research results relates to the differential assessment of certain religious motives. This 
primarily refers to the Emperor's Mosque and the Cathedral of the Sacred Heart, which were rated somewhat lower value compared to the Bey Mosque and according to the total frequency of evaluation they have a regional character. Possible reasons are that the Emperor's Mosque in the period 2013-2014 was partly under reconstruction and renovation. In the case of the Cathedral, the lower rating could be affected by the religious structure and orientation of tourists (over 40\% Muslim tourists). Churches that are reminiscent of the Sarajevo cathedral can be found in some European destinations such as the Church Sint-Brigidakerk in Geldrop (the Netherlands).

Natural motives, such as the Spring of the Bosnia River and Bijambare, have great tourism value because according to the total frequency of evaluation they have national and regional importance. The valuation of the Spring of the Bosnia River is identical in most authors who have studied the valorization of this motive. Natural Monument of "the Spring of the Bosnia River" includes the extreme southwestern part of the Sarajevo plain and direct contact mountain rim. The full protected area and the wider region have the above-average amount of surface water and groundwater which represent great specificity and attractiveness. First of all, these are the springs of the Bosnia River whose number is about 30 on the whole area. The total average water abundance of all springs that are collected by the course of the river upstream from the Roman bridge is $5-24 \mathrm{~m} 3$ / sec, which is quite enough to directly form one of the largest rivers in $\mathrm{BiH}$ the Bosna river. In this area there is a high degree of biological diversity characterized by the existence of 99 indigenous and alochtonous dendrotaxons, over 200 herbaceous species, about 35 species of honey and medicinal plants, 20 species of mammals and 52 species of birds. (Đug, Drešković, Hamzic, 2008, pg 176-179) The Spring of the Bosnia River is treated as a unique complex of "integral heritage". Specific natural values are: hydrological (the Spring of the Bosnia River, the Spring of the Stojčevac, Sulfur Spa Ilidža) and horticultural (the Big Alley, Spa Park Ilidža). (Spatial Plan for Sarajevo Canton for 2003-2023, 2006, pg 44) However, the results of the valuation of Bijambare showed a higher ranking (formerly regional). There is no doubt that the area of Bijambare has recently significantly improved by their total content (visit and tour of the caves, gastronomy, recreation, train eco-driving). The conservation of Bijambare in the context of protected landscapes and contemporary activities related to the valorisation of the tourism-recreational and educational purposes has led to significant progress and recognized the beauty of this area. "The Protected Landscape of Bijambare" belongs to the area of the central Bosnian Dinarides, located above the mountains Stars, Ozren and Čemernica. A wider area consists of a less morphological depression in the drainage of Ljubina, Misoča, Krivaja and streams of Bjelila. Along the peripheral part, three caves were created at various altitude levels. In the area of Bijambare, there were found 133 different environmental communities of an association level. Their structure consists of more than 800 species of higher plants. There are also numerous representatives fauna- mammals, birds, reptiles, amphibians, mollusks, insects. The area allows conservation of ecosystems and the extraordinary possibilities 
of research, monitoring, education and recreation.“ (Đug, Drešković, Hamzic, 2008, pg 179-181)

The Sarajevo War Tunnel Dobrinja-Butmir (the Tunnel of Hope) has the recognized national and wider tourism importance. Results of earlier reasearch in different authors showed a lower value of regional importance. However, interest in unusual and unique motives such as the Tunnel of Hope, with which binds a significant part of the modern and difficult history of Sarajevo, certainly gives greater tourist importance to this motive. The symbolism of the tunnel and museum, which demonstrate the true story of the not-so-long siege of Sarajevo, produce strong emotions and deep impression with tourists visitors. The fact that the war in the overall image of Sarajevo tourism destination accountes for $60-70 \%$ arouses great interest in visiting this site. "The museum of the siege of the city- the Tunnel of Hope, a monumental complex war Tunnel Dobrinja-Butmir, the Sarajevo War Tunnel was built during the aggression on Sarajevo and Bosnia and Herzegovina (1992-1995). The only way to get out of besieged Sarajevo to the free territory was running across the airport runway. At the end of 1992, the Bosnia \&Herzegovina Army presented the idea to make a project to build an underground tunnel under the Sarajevo airport. Starting points were determined in Dobrinja and Butmir and the project was completed in 1993. The tunnel was built under difficult wartime conditions with a lack of resources and under constant shelling. At the very beginning of the building, everything was carried on backs and arms. There were carried food, cigarettes, oil, ammunition, weapons, drugs, but also the wounded people. Subsequently, rails were mounted, so that the transportation was facilitated by small wagons. Through the tunnel telephone lines were set up between Sarajevo and the free territory. For the tourists who nowadays visit the Museum of the Tunnel of Hope, it is unthinkable that a few hundred people depended on a small narrow passage under the Airport. The surviving part of the tunnel as well as the exhibits in the accompanying museum preserve a memory of the courage of the citizens of Sarajevo and their struggle for survival. There is no doubt that the Tunnel of Hope played a key role in the defense of Bosnia and Herzegovina and its capital Sarajevo." (Kolar \& Kolar, 2008) The Sarajevo War Tunnel (Tunnel of Hope, Tunnel Dobrinja-Butmir) is currently on the list of petitions for the national monuments of Bosnia and Herzegovina. (Commission to Preserve National Monuments)

Cultural and historical motives such as City Hall and Svrzo house, and Latin Bridge, are valued with medium grades and according to the total frequency have a regional tourism importance. The Latin Bridge (Princip's bridge 1918-1992) is a bridge located on the Miljacka river near the park At Mejdan and the Museum of Sarajevo 1878-1918, in the old town close to the Baščaršija. The Latin Bridge in its present form was built in 1798, the bridge has four arches and three support pillars; it was built of stone and plaster. Due to the intense traffic in the Austro-Hungarian period, the construction of the bridge was boosted. The Latin Bridge has a favorable tourism-geographical position, it's well preserved, and is an important factor in tourism as it connects the right and left side of the city that is rich in various monuments of cultural heritage and 
that is very interesting for tourists. In addition to its history and unique appearance, it is interesting for tourists because it represents an important witness to the events that had an effect on the whole world, and that is Gavrilo Princip's assassination of the AustroHungarian Archduke Franz Ferdinand and his wife Sofia in 1914. This assassination is taken as a pretext for the start of the First World War. The Latin Bridge was declared in 2004 a national monument of Bosnia and Herzegovina. (The Commission to Preserve National Monuments of BH, 2011) However, a slightly lower grade than with most other authors (national importance) is most likely a result of poor impression with tourists. Although the Latin Bridge is a symbol of the world historical event, it does not have particularly prominent visually-appealing attributes itself. Limiting factors are linked to weaker attractiveness of the organization of elements in this area: in the immediate vicinity of the bridge is a tram stop, intersection and high traffic of people, and the surrounding buildings and facilities require better incorporation into environment (they require restoration, refreshment, harmonization of style and colors) in order to increase the dose of enthusiasm. The words of praise and recognition of individual motives depend on experience and impressions. On the other hand, the reasons for a lower assessment of the City Hall and Svrzo House are of somewhat different nature. From a conversation with tourists it was learned that a number of them did not visit Svrzo Houseas they were apparently informed that the access was somewhat harder. This motive is located in the old town in a suburban residential area of Glođina. The streets are narrow, sloping and of a larger radius of curvature, but the access of the motives is completely adapted. It is necessary to work on more quality promotion of Svrzo House and to motivate tourists to visit it (foreign guides largely avoid bringing groups to this site). Svrzo House (kadi Munib effendi Glođo) represent the housing culture of bosnian muslim family at the end of 18 . and thrue the 19. century (the cultural monument). The House is bosnian-oriental architecture, it is devided into 2 parts: selamluk (the public receptive part) and haremluk (the private family part). When it comes to the City Hall, slightly lower ratings can result from a number of reasons. First, an apparently similar City Hall is located in Brčko District. This can reduce impressions with tourists from the country and the region. Second, the architecture of the City Hall and motives that are largely mapped from Egyptian objects and in the Arabic style may not be particularly attractive to tourists of the Arab origin, who have a large participation in the overall structure of tourist visitors. "The City Hall is the most beautiful and the most representative anthropogenic motive of the Austro-Hungarian period built in the Pseudo-Moorish style. The implementing project shows the dominant influence of Islamic art from Egypt and Spain. For details, there were taken detailed studies of the architect A. Wittek as the basis, who worked according to the Sultan Hassan and Kait Bey's mosques from the 15th century in Cairo." (Ćeman, 2004, pg 48). From the point of tourist interest, the City Hall had the Department of Rare Books and Manuscripts, which collected the material of the highest monument category: incunabulas, old manuscripts written in Bosnian Cyrillic, collection of oriental manuscripts with about 400 codes and 700 individual documents, manuscripts of local 
authors in oriental languages, editions of foreign printing. The City Hall as the National and University Library was important for the entire region. The City Hall was declared a national monument of Bosnia and Herzegovina in 2006. (Commission to Preserve National Monuments, 2011)

The Pioneer Valley Amusement Park and Zoo has been valued with good grades and a regional tourist importance. It is identically evaluated by other authors. The significance of this motive in the future is likely to grow because of the increasing number of visitors from the Arab countries. Why is this particularly important? Precisely because these are family tourists with a large number of children. Amusement parks in such cases represent an excellent opportunity for rest. Arabs have expressed particular satisfaction with such motives. This park is located on NE of Sarajevo on the distance from urban centre only $2 \mathrm{~km}$. Total area is $8.5 \mathrm{ha}$. The place is rich in flora and fauna, it enables a various horticultural activities. The recreative part include props for children's play and fun (circuit, cars to electric drive train, rubber town, cars, carousel), children's park and playground with slides, swings, seesaws and the zoo. It is ideal resting place for the family with kids.

\section{CONCLUSIONS}

Sarajevo is a developingtourism destination, the tourism has a positive upward trend. Based on the identification of natural and anthropogenic motives, it is undeniable that there is a huge potential for tourism which offers excellent possibilities for tourism planning and rich tourism supply. Sarajevo is unique city because it's very multhiethnic and multicultural; it's a place of three monoteistic religions: islam, christianity and judaism, that's why it is so specific destination in Europe.Ithas a wealth of different motives (natural \& cultural heritage) which have the recognized tourism value. Earlier and the latest research results concerning the valuation of the motives point to a unique conclusion that the biggest tourism value and international importance has Baščaršija, and therefore this motive/ site fully meets the requirements for inclusion on the UNESCO list. On the other hand, the new results give the bigger tourism importance to some other motives/ attractions such as Tunnel of Hope, Springs of Bosnia and Bijambare. For the planning of tourism supply and development of tourism, of great importance will be the results of the valuation of motives to the frequency of impressions of tourists and tourism managers, because the interests of tourists and their experience create new demand and supply market. Particularly important are tourist assessments on which affirmation of the motives and destination in the world will largely depend, and thus their further use and promotion. An evidence that Sarajevo has been developed into a worldwide tourist destination is an increasing influx of foreign tourists, not only from the region (Balkan), Europe and Turkey, but also from distant parts of the world (South Korea, Australia, Canada, Malaysia, the United States, the Arab countries: Kuwait, the UAE, Qatar). The overall conclusion is that Sarajevo tourism destination is gaining in global importance. 


\section{REFERENCES}

1. Bakaršić, S. (1966): "Genesys of Sarajevo". Geographical Reviews, sv. X, Association of geographers of Bosnia and Herzegovina, Sarajevo

2. Bejtić, A. (1969): "The old town "čaršija" of Sarajevo yesterday, today and tommorow: fundamentals and guidelines for regeneration." City Institute for the Protection and Preservation of Cultural Monuments, Sarajevo

3. Bušatlija, I. (1974): "Morphostructural and morphosculptural characteristics of relief of Bosnia and Herzegovina." Proceeding IX Congress of geographers from Yugoslavia in Bosnia and Herzegovina. Association of geographers of Bosnia and Herzegovina, Sarajevo, pg 133-135

4. Collegium "Tourism" (2010): "Tourism resources and attractions". Ppt. Faculty of Economics University of Zagreb, Zagreb

5. Commission to Preserve National Monuments of Bosnia and Herzegovina (2005).Resolution for the national monuments declaration and tentative list of monuments, Bosnia and Herzegovina, 2005, Sarajevo

6. Ceman, M.H. (2004): "Restauration of the City Hall in Sarajevo." Stonemasonry and sculpturality, vol. 1-2, XV, School for stonemasonry, Brač

7. Džaferović, S. (2011): "Tourist motivation for visiting Sarajevo." Graduate paper. Menthor: PhD R. Šećibović. Faculty of Sarajevo University of Sarajevo, Sarajevo

8. Đug, S., Drešković, N., Hamzić, A. (2008): "Natural heritage of Canton Sarajevo". Cantonal Institute for Protection of Cultural and Natural Heritage, Sarajevo

9. Hall, M., Page, S. (2014): "The Geography of Tourism and Recreation: Environment, Place and Space". Routledge, The Fourth Edition, New York, USA, pg 210-211

10. Jašarević, S. (2012): "Identification, valorization, ranking and mapping of anthropogenic tourist attractions on the tourist corridor Bihać-Jajce-TravnikSarajevo-Višegrad". Master paper. Faculty of Sarajevo University of Sarajevo, Sarajevo

11. Jianchang, C., Jigang, B. (1988): "A Study of Tourist Behavior and its Practical Significance". Geographical Research, 1988, vol. 7 (3): 44-51

12. Jovičić, Ž. (1986): "Tourism geography". Scientific Book, Belgrad

13. Jovičić, Ž. (1992): "Fenomenology of tourism". Scientific Book, Belgrad

14. Kolar, B., Kolar, E. (2008): "The Tunnel." Brochure Museum of The Tunnel of Hope, Sarajevo

15. Kurto, N. (1997): "Sarajevo 1462-1992." Oko, Sarajevo

16. Mehičić, I. (2007): "Tourist product of Canton Sarajevo- Sarajevo quality- basic elements". Chamber of Economy of Sarajevo Canton, Sarajevo

17. Mehmedović, A. (2005): "Gazi Husrev Bey and his endowment". Author's edition, Sarajevo

18. Museum of City of Sarajevo (1963): "Contributions to the study of history of Sarajevo." Book I, Sarajevo 
19. Nurković, S. (2006): "Regional aspect of tourism potentials in Canton Sarajevoclassification and evaluation." Proceedings Tourism as a factor of regional development, Faculty of Sciences of University of Tuzla, pg 31-43

20. Popara, E. (2012): "Identification, valorization, ranking and mapping of anthropogenic tourist attractions of Sarajevo as a tourist region." Master paper. Faculty of Sciences University of Sarajevo, Sarajevo

21. Spatial plan of Bosnia and Herzegovina, phase B valorization: the natural, cultural and historical value (1980). Institute for architecture, urbanism and spatial planning, The Faculty of Architecture University of Sarajevo, Sarajevo

22. Spatial plan of Canton Sarajevo for the period of 2003-2023 (2006). Development Planning Institute of the Sarajevo Canton, Sarajevo

23. Stanković, S. (2000): "Tourism geography". University of Belgrad, Belgrad

24. The Archive of Federal Office of Statistics (2009). Electronic data base. Federal Bureau for Statistics, Sarajevo, Federation of Bosnia and Herzegovina, Bosnia and Herzegovina

25. The Survey Guideline (2001): "Approaches to the Analysis of Survey Data". Statistical Services Centre, The University of Reading, United Kingdom

26. UNESCO »Culture», World Heritage Centre, »The List», Global Strategy, Tentative List, "Sarajevo - unique symbol of universal multiculture - continual open city", 1992-2015

27. Zelenika, R. (2000): "Methodology and techniques of scientific and professional work". Faculty of Economics, University of Rijeka, Rijeka

28. Žunić, L. (2013): "Survey for employers in tourism". Sarajevo, 2013

29. Žunić, L. (2013-2014): "Survey for tourists- the visitors". Sarajevo, 2013-2014

30. Žunić, L. (2016): "Tourism of Sarajevo- evaluation of receptive antropogenical factors and its importance for planning the tourist offer". Doctoral dissertation. Mentor: PhD Kristina Košić. Faculty of Sciences of University of Sarajevo, Sarajevo

31. URL-1: http://kons.gov.ba

32. URL-2:

http://kons.gov.ba/nacionalni_spomenici/privremena lista/Default.aspx?id=7281\&1 angTag=bs-BA

33. URL-3: https://en.wikipedia.org/wiki/Sarajevo

34. URL-4: http://sarajevo.travel/en/text/discover-why-sarajevo-is-called-a-europeanjerusalem $/ 202$

35. URL-4: http://www.sarajevo.ba/ba/stream.php?kat=424

36. URL-5:

https://upload.wikimedia.org/wikipedia/commons/thumb/4/45/Bosnia and Herzeg ovina topographic map.svg/2000px-

Bosnia and Herzegovina topographic map.svg.png

37.URL-6: https://publi.cz/books/55/04.html 